\title{
Analysis of the Necessity for Heutagogical Approach Through 4Cs Skills as Innovation for Vocational Lectures in the Education 4.0
}

\author{
Andika Bagus Nur Rahma Putra ${ }^{1}$, Haris Anwar Syafrudie ${ }^{2}$, Jailani Md Yunos ${ }^{3}$, Ahmad Mursyidum \\ Nidhom ${ }^{4}$, Azhar Ahmad Smaragdina ${ }^{5}$, Andrew Irfano Sembiring ${ }^{6}$ \\ ${ }^{1,4,5,6}$ Dep. of Mechanical Engineering, Faculty of Engineering, Universitas Negeri Malang, Indonesia \\ ${ }^{2}$ Dep. of Civil Engineering, Faculty of Engineering, Universitas Negeri Malang, Indonesia \\ ${ }^{3}$ Dep. of Computer Engineering, Faculty of Electrical and Electronic Engineering, Universiti Tun Hussein Onn \\ Malaysia, Malaysia \\ andika.bagus.ft@um.ac.id,hriso@hotmail.com, jailani@uthm.edu.my,nidhom.ft@um.ac.id, \\ azhar.informatika@gmail.com, andre366irfanos@gmail.com
}

Keywords: heutagogical approach, 4Cs skill, vocational education, education 4.0, 21st-century skill

\begin{abstract}
This study aims to: (1) analyze the level of need for the heutagogical approach through 4Cs on aspects of creativity; (2) analyze the level of needs of the heutagogical approach through $4 \mathrm{Cs}$ in the communication aspect; (3) analyze the level of needs of the heutagogical approach through 4Cs in aspects of critical thinking; and (4) analyze the level of need for the heutagogical approach through 4Cs in the collaboration aspect. This study uses a qualitative method. Data collection techniques with interviews, literature review, documentation, and observation. Informants included lecturers, students, and stakeholders at the State University of Malang and used a sampling technique namely purposive sample. Data analysis techniques used are data reduction, data interpretation, and triangulation. Conclusions from this study indicate that: (1) the level of need for aspects of creativity includes the ability to: develop ideas (83.6\%), express creative ideas $(81.2 \%)$, adapt to new environments $(88.2 \%)$, and creative independence $(88.4 \%)$; (2) the level of need for communication aspect includes the ability to convey information (79.8\%), express ideas $(82.2 \%)$, accept opinions $(84.2 \%)$, master various communication techniques (78.1\%); (3) the level of need for Critical Thinking aspects including the ability to: evaluate $(90.1 \%)$, identify problems $(89.2 \%)$, solve problems $(92.2 \%)$, distinguish facts from assessment (82.8\%); and (4) the level of need for the Collaboration aspect includes the ability to: cooperate $(89.6 \%)$, full responsibility $(84.2 \%)$, respect differences $(82.2 \%)$, discuss $(87.6 \%)$.
\end{abstract}

\section{INTRODUCTION}

In the 21 st century, education is becoming increasingly important to guarantee human resources who have learning and innovation skills. Also, in the 21 st century, it encourages skills in using information technology and media, and can work, and survive by using life skills. (Fitzgerald et al., 2016; Tekerek and Karakaya, 2018; Skorton, 2019). At present, the phenomenon of degradation in capability of college graduates continues to increase. Some experts state that more than $75 \%$ of college graduates have not worked by their fields of expertise (Irdianto and Putra, 2016; Mukhadis et al., 2018). This prompted many developed countries to accelerate the improvement of the capabilities and integrity of education actors. No exception in countries in Southeast Asia. Some countries such as Malaysia, Thailand, Singapore, Brunei, including Indonesia, continue to develop innovations and conduct in-depth studies on alternatives to improving the quality of education, especially vocational education (Karlsson, Nilsson and Nilsson, 2018; Hashim et al., 2019; Kintu, Kitainge and Ferej, 2019). Vocational education is one of the main 'weapons' and is at the very front when a country experiences an educational revolution (Lang et al., 2017; Forster and Bol, 2018; Mesfin and Niekerk, 2019).

As an impact, in the 4.0 Industrial Revolution. This, vocational education is required to continue to skyrocket and capture every innovation in the learning process (Jantan et al., 2018; Zaharah et al., 2018; Vu and Le, 2019). Facing the challenges in the digitalization era, vocational education is required to continue to follow the revolutionary cycle. Some experts stated that the era of education that was influenced by the 4.0 industrial revolution was called Education 4.0 (Jantan et al., 2018; Zaharah et al., 
2018; Murtikusuma et al., 2019; Vu and Le, 2019). Education 4.0 is an education characterized by the use of digital technology in the learning process or known as a cyber system. The quality of educators in this case lecturers must be by the performance of lecturers needed in the industrial era 4.0. Vocational education is an important means of transforming and improving society, so it must have a global connection because global activities have an impact on education (Lang et al., 2017; Jossberger et al., 2018; Placklé et al., 2018; Dang, Wang and Kang, 2019).

One form of cutting-edge learning innovation to build students' revolts thinking is the heutagogy approach. In the field of heutagogy education, the concept was first created by Stewart from Southern Cross University. The study is a study of learning that is self-determined by self-learning (Oliver, 2016; Green and Schlairet, 2017; Stoszkowski and Collins, 2018; Stoszkowski et al., 2018). This idea is an extension of the reinterpretation of the andragogical approach. Heutagogi press points are devoted to the improvement of learning how to learn, double loop learning, the opportunity to learn thoroughly, and focus on developing skills (Jones, 2016; Praherdhiono, Adi and Prihatmoko, 2018; Stoszkowski et al., 2018).

The heutagogical approach to vocational education emphasizes the human nature of human resources, self-worth, ability, and recognizes natural systems that interface the environment and learning activities as opposed to teaching. Heutagogi discussed issues of human adaptation in order to enter the new millennium (Green and Schlairet, 2017; McCarthy, Stoszkowski and Robert, 2018; Mulrennan, 2018; Stoszkowski and Collins, 2018). This model challenges ways of thinking more than processes rather than content, allowing learning to better understand their world than the world of the teacher, forcing teachers to move into the world of learners, and allowing teachers to see beyond their own disciplines and favorite theories (Brien, 2018; Marcut and Chisiu, 2018).

In vocational education, teaching strategies must be designed to meet specific requirements using flexible teaching methods that accommodate various approaches. Vocational education (technical education) helps develop individuals of science and technology knowledge in a broad field of work that requires technical and professional competencies and specific work skills (Placklé et al., 2018; Smirnova et al., 2019; Thunqvist, Tønder and Reegård, 2019). If important parties improve technical education in all its forms, then there is a need to understand the teaching and learning methods that make it work well. It is characteristic of the demands of 21st-century skills or termed 4C (Communication, Collaboration,
Critical Thinking and Problem Solving, and Creativity and Innovation) (Ivanov, 2016; Melo, 2018; Robi, Hobri and Dafik, 2018).

In this $4 \mathrm{C}$ skill, lecturers are encouraged to be able to map their students' thinking skills. The ability to think in vocational education includes knowledge of perception and creation (Ericson, Parker and Engelman, 2016; Chidiac and Ajaka, 2018; Handajani, Pratiwi and Mardiyana, 2018). An ability to think is an ability to use the mind to search for meaning and understanding of something exploring ideas, making decisions, thinking about solutions with the best consideration and revising problems in previous thought processes. As an agent of change, students must be able to show their identity in intellectual, moral and elegant ways (Santos et al., 2018; Zaharah et al., 2018). Therefore, in the 21st century, the learning process carried out in higher education must be truly considered, in order to produce competent graduates.

\section{METHOD}

In this study, the method used is a qualitative method. Data collection is done by interviews, literature review, documentation, and observation. Research instruments used were questionnaires, interview guidelines, and observation guidelines. The research subjects included lecturers, students, and stakeholders at Malang State University. The informants in this study included 30 vocational lecturers, 100 vocational students, and vocational field stakeholders. The sampling technique used is purposive sample. Data analysis techniques used are data reduction, data interpretation, and triangulation. Schematically, the research stages are shown in Figure 1.

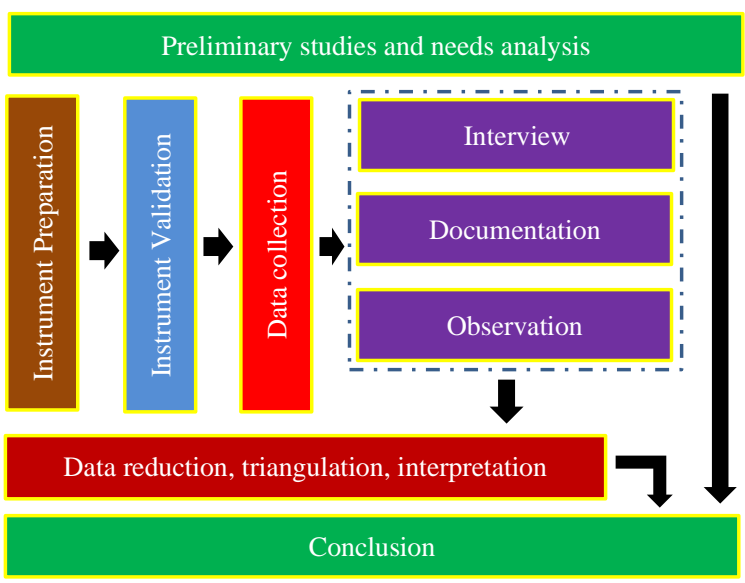

Figure 1: Research stage scheme 
In the instrument validation process, carried out by two expert teams. The first expert is a vocational material expert. The second expert is linguists and literature experts. Both experts have a high level of professionalism.

\section{RESULT}

In this study revealed several significant findings. The findings cover aspects needed in carrying out the heutagogy approach through 4Cs skills. These aspects include aspects of creativity, communication aspects, Critical Thinking aspects, and Collaboration aspects. In the aspect of creativity, the level of need for needed abilities is shown in Figure 2.

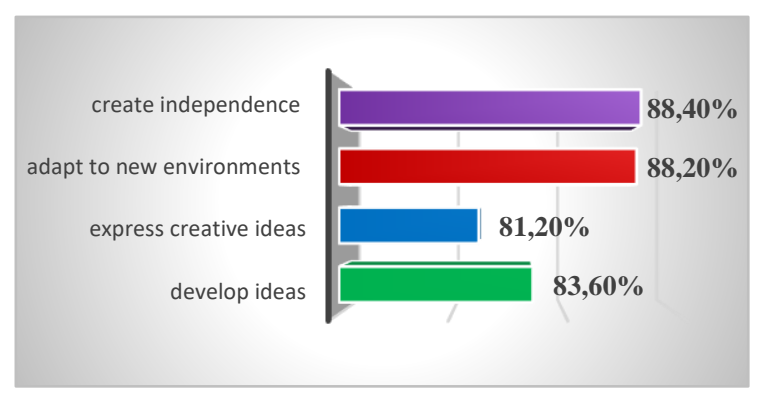

Figure 2: Level of Creativity Aspect capability requirements

In Figure 2, it can be seen that the level of need for aspects of creativity includes four needs. The percentage level of capability needs in each component includes developing ideas (83.6\%), expressing creative ideas $(81.2 \%)$, adapting to the new environment (88.2\%), and creating independence (88.4\%). Furthermore, the level of need for capabilities needed in the communication aspect is shown in Figure 3.

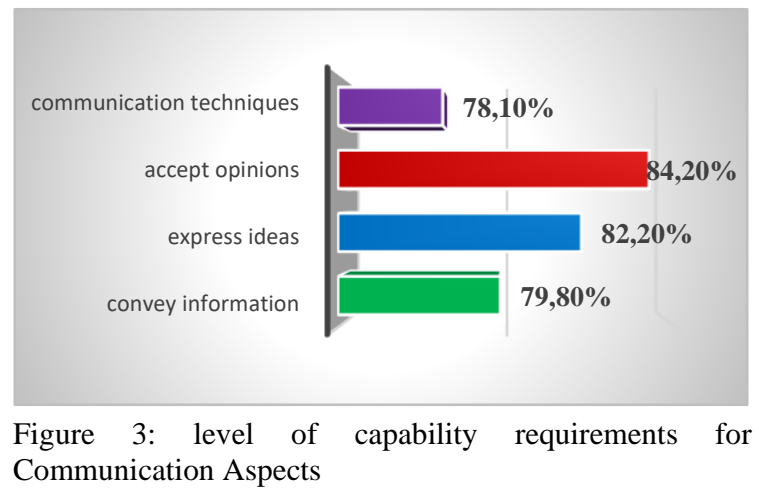

In Figure 3, it can be seen that the level of needs in the communication aspect includes four needs.
Percentage of level of ability needs in each component includes ability: convey information $(79.8 \%)$, specific ideas $(82.2 \%)$, accept opinions $(84.2 \%)$, master various communication techniques (78.1\%). Furthermore, the level of capability needed in the Critical Thinking aspect is shown in Figure 4.

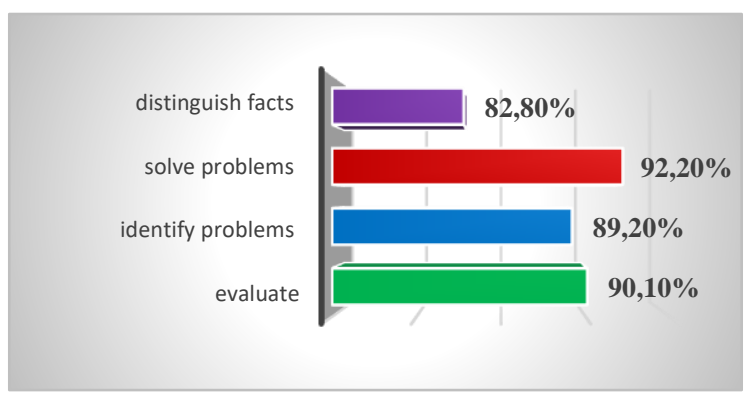

Figure 4: the level of capability needs of the Critical Thinking aspect

In Figure 4, it can be seen that the level of need for Critical Thinking aspects includes four needs. The percentage level of ability needed in each component included the ability: evaluating $(90.1 \%)$, identifying problems (89.2\%), solving problems (92.2\%), distinguishing facts from assessment (82.8\%). Furthermore, the level of capability requirements needed in the Collaboration aspect is shown in Figure 5.

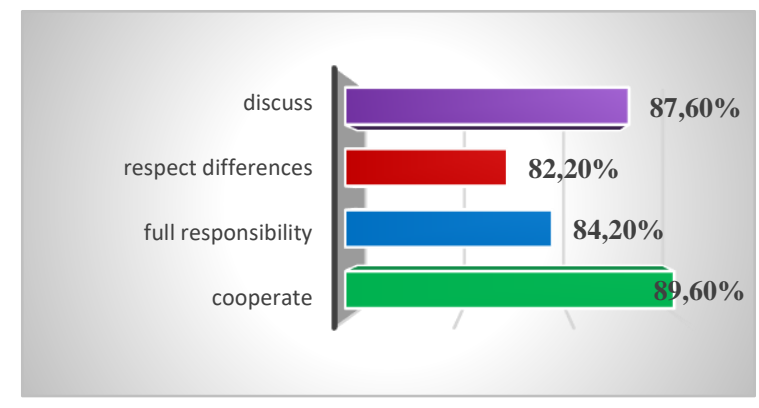

Figure 5: level of need for Collaboration Aspect capabilities

In Figure 5, it can be seen that the level of need for the Collaboration aspect includes four needs. The percentage level of ability needs in each component includes the ability: collaboration (89.6\%), full responsibility $(84.2 \%)$, respect for differences $(82.2 \%)$, discussion $(87.6 \%)$.

\section{DISCUSSION}

In this study several important analyzes were found. The analysis in this study was discussed based 
on the findings that have been obtained. The discussion covers three things. These are (1) creativity and communication in the concept of the heutagogical approach; (2) Critical Thinking and Collaboration as characteristics of the heutagogical approach; and (3) the need for 4Cs skills on the heutagogical approach.

\subsection{Creativity and Communication in the Concept of the Heutagogical Approach}

This study reveals that the aspects of creativity and aspects of communication are vital needs in the part of the heutagogy approach. In the aspect of creativity, there are four main needs. These needs include the ability to develop ideas, the ability to express creative ideas, the ability to adapt to new environments, and the ability to create independently.

In the concept of the heutagogy approach, the level of creativity is a major factor in the development of activities in the classroom (Richardson, Mcgowan and Styger, 2017; Brien, 2018; Mulrennan, 2018). By its role, a lecturer has full ability to manage his class. Various situations and conditions in the class must be able to be controlled by a lecturer through creative steps. The ability of a lecturer to develop ideas is needed to stimulate students (Irdianto and Putra, 2016; Putra, Irdianto and Mukhadis, 2016; A. B. R. N. Putra et al., 2018). By the concept of the heutagogical approach, that human beings essentially have an idealistic spirit of learning. Some experts suggest that people want to learn and have a natural tendency to do it throughout life (Bacca, Baldiris and Girona, 2018; Karlsson, Nilsson and Nilsson, 2018; Placklé et al., 2018; Mesfin and Niekerk, 2019). That will create a positive cycle in the learning process in the classroom.

At present, the main control of the class is determined by the ability of a lecturer to initiate a learning transaction. Creative ideas must be able to harmonize the needs of students in learning a material, especially material in the field of vocational (Dang, Wang and Kang, 2019; Haris et al., 2019). In this era of education, 4.0 learning has unlimited scope. Also, students have full authority over the knowledge they want to learn (Murtikusuma et al., 2019; Vu and Le, 2019; Zambon et al., 2019). If it is interpreted more deeply, it is by the main concept of heutagogy. The heutagogical approach offers how people learn, be creative, have high self-efficacy, can apply competencies in life situations, and be able to work with others (Thakur, 2017; Mulrennan, 2018; Stoszkowski et al., 2018; Narayan, Cochrane and Herrington, 2019). The class situation that is not always perfect is a challenge that must be solved by a lecturer. Lecturers are required to be able to control and manage uncontrolled phenomena in the learning process. This is directly proportional to the basic concept of the heutagogical approach. The heutagogical approach emphasizes the human nature of human resources, self-worth, ability, and recognizes systems between the environment and learning activities as opposed to teaching (Green and Schlairet, 2017; Brien, 2018; McCarthy, Stoszkowski and Robert, 2018).

An important aspect found in this research is the communication aspect. In this aspect, there are four main needs elements. These needs include the ability to convey information, the ability to deliver ideas, the ability to accept opinions, and the ability to master various communication techniques. The four elements are by the characteristics of the education era 4.0 which requires lecturers to have top-level interaction skills (Richardson, Mcgowan and Styger, 2017; Thakur, 2017; Mulrennan, 2018).

Direct interaction with students when in class, forcing a lecturer to master the ability to convey information well. Submission of information should be packaged through representative and communicative language. That is because in the field of vocational learning, the information conveyed must be scientific and supported by relevant sources (Karlsson, Nilsson and Nilsson, 2018; Mesfin and Niekerk, 2019; Smirnova et al., 2019). Moreover, in the 21 st century, there is a lot of garbage information whose truth cannot be assessed. Some experts say that the ability to convey information is an absolute ability to develop a heutagogical approach (Malek, 2017; Marcut and Chisiu, 2018; Stoszkowski et al., 2018; Narayan, Cochrane and Herrington, 2019). Heutagogy places students truly responsible for what is learned and when they learn. In addition, the heutagiogi approach also provides a framework for learning that places responsible adults to be more advanced (McCarthy, Stoszkowski and Robert, 2018; Mulrennan, 2018; Narayan, Cochrane and Herrington, 2019).

The ability of a lecturer to express creative ideas will make the classroom atmosphere livelier and more positive. Information and stimulation of the problems presented to students need to be filtered so that it becomes a problem that requires creative solutions (Fırat, Kılınç and Yüzer, 2018; Chan, 2019; Elyakim et al., 2019). In the heutagogical approach, students consider the problems and actions produced and the learning outcomes. Furthermore, they reflect on the problem solving process and how it affects their own beliefs and actions (Malek, 2017; Thakur, 2017; McCarthy, Stoszkowski and Robert, 2018). 
The impact of this is that students will be able to respond and follow up with their lecturers through smart thoughts. The implication is that in the heutagogical approach, a lecturer must be able to accept every opinion and opinion from his students (Mulrennan, 2018; Praherdhiono, Adi and Prihatmoko, 2018; Stoszkowski and Collins, 2018). Based on that, then various interactive communication techniques must be mastered by a good lecturer. Some experts stated that the education era 4.0 was an era that won an educator with a good level of communication (Mudin et al., 2018; Murtikusuma et al., 2019; Vu and Le, 2019).

\subsection{Critical Thinking and Collaboration as Characteristics of the Heutagogical Approach}

Another thing revealed in this study is that the characteristics of the heutagogical approach are strongly influenced by Critical Thinking aspects and collaboration aspects. In the aspect of critical thinking, four main elements are found. These elements include the ability to evaluate, the ability to identify problems, the ability to solve problems well, and the ability to provide facts from assessment.

Vocational education cannot be separated from the influence of the needs of the industrial world and the business world. In the era of education 4.0 a lecturer must often carry out analysis and evaluation of learning (Jose and Ramakrishna, 2018; Ślusarczyk, 2018; Mukri and Anwar, 2019). The evaluation in question is always trying to synchronize every transaction carried out in class with every step of the development of the industrial world and the business world. By the characteristics of the heutagogical approach that puts independence above everything. By the concept, if students can reproduce knowledge and skills in unfamiliar situations, this is called double-looping. This ability is a reflection of the student's competence. Without competence there is no ability. Through a double-looping process, students will become aware of a learning approach where they are adaptable so that they become more competent (MayTruong, 2016; Firat, K1lınç and Yüzer, 2018; Mcguinness and Fulton, 2019; Ramírez, 2019).

Some experts explain that in the vocational field there are often problems that are relatively complicated to solve (Lang et al., 2017; Bacca, Baldiris and Girona, 2018; Dang, Wang and Kang, 2019; Kintu, Kitainge, and Ferej, 2019). Moreover, in this era of education 4.0, problems that often arise are often caused by a person's inability to interpret the phenomenon at hand (Mahmood and Hussin, 2018; Mukri and Anwar, 2019; Zabidin, Belayutham and
Ibrahim, 2019). Therefore, it is very important for a lecturer to master the ability to identify problems that will be presented to his students through a heutagogical approach. The heutagogical approach can be seen as a development from pedagogy to andragogy. Smart students only need a little control from their lecturers, and of course, they will become more independent in learning. On the other hand, students who are less intelligent will need more guidance from their lecturers (A. B. N. R. Putra et al., 2018; Mukhadis et al., 2018).

A lecturer must be able to provide an easy bridge that helps students solve problems given in class. Often students ask the problems they face to their lecturers. In this context, a lecturer is tested for his ability to solve problems correctly (Owston, York and Malhotra, 2018; Simarmata et al., 2018; Montgomery et al., 2019). The learning process in the field of vocational education is indeed formed from unique phenomena that exist in life. The main thing that must be seen from this is that each must try to overcome the problems faced. The first is to consider various problems that occur in general as a consequence of social change in society. Second, the decomposition of the subjective meanings of individual changes in the field of education (Anggariana et al., 2017; Bahçıvan, 2017; Yakar and Turgut, 2017).

The next aspect that reinforces the characteristics of the heutagogy approach is the aspect of collaboration. In this study, there were four main focus points for the needs of the heutatogy approach. The needs of these capabilities include the ability to cooperate, the ability to be fully responsible, the ability to appreciate opinions, and the ability to interact interactively.

Vocational education has a linear nature of technological and industrial developments. Not only in the era of education 4.0, the pace of industrial revolution 4.0 has dragged every thought into being able to cooperate in meeting the demands of progress (Cirp et al., 2018; Jantan et al., 2018; Zaharah et al., 2018; Idris, 2019). Based on the principle of the heutagogical approach, a lecturer must be able to cooperate with everything that is able to make his competence develop. Lecturers must also be able to collaborate with their students in a complex manner to develop a new innovation. A lecturer must be strong in creating new innovations and accepted by society (Santos et al., 2018; Rahman et al., 2019). Through a collaborative process, lecturers must compete to create ideas that will be developed for technological progress.

The concept of heutagogy in the field of vocational education has a meaning that offers certain principles and practices that can be considered as 
responses to developments in higher education (Green and Schlairet, 2017; Praherdhiono, Adi and Prihatmoko, 2018; Stoszkowski and Collins, 2018). The heutagogic learning environment facilitates the development of capable learners and emphasizes both student competency development and the development of learners' abilities and capacities for learning. The main concept in heutagogy is double-loop learning and self-reflection. In double-loop learning, students consider the problem and the results of actions and results, in addition to reflecting on the problem-solving process and how it affects the learner's own beliefs and actions (McCarthy, Stoszkowski and Robert, 2018; Stoszkowski et al., 2018). Double loop learning occurs when students question and test one's values and assumptions as a center for improving learning in learning.

\subsection{The Need for 4 Cs Skill in the Heutagogical Approach}

Education plays an important role in preparing generations who can compete in the age of globalization accompanied by rapid advances in modern technology. In this era of education 4.0, vocational education must also be immediately changed or transformed from traditional learning into modern education. That is because to ensure students have the knowledge, learning and innovation skills, the skills to use technology to find information, and to survive by using skills for life skills (Lang et al., 2017; Newton et al., 2018; Woessmann, 2019). Universities should be able to equip students with the various competencies above so that they can compete in the education era 4.0. Students are directed to think critically so that they can identify problems, process problems, and conclude problems that exist so that they gain a deeper understanding of the surrounding environment. It is by the characteristics and principles of the heutagogical approach. (Richardson, Mcgowan, and Styger, 2017; Stoszkowski and Collins, 2018; Narayan, Cochrane and Herrington, 2019).

The reality now is that the thinking ability of lecturers is not in line with expectations and needs to be improved. The development of 4Cs skills (creativity, communication, Critical Thinking, and Collaboration) is an absolute skill that must be mastered by all lecturers in the field of vocational (Chidiac and Ajaka, 2018; Robi, Hobri and Dafik, 2018; Zulkarnaen et al., 2019). Also, the focus of problem-solving is relatively low, indicating that solving problems requires high-level thinking skills. Thinking ability is one of the capabilities that need to be developed to face the challenges of the $21 \mathrm{st}$ century. Some experts identify 21 st century capabilities including creative and innovative (creativity and innovation), critical thinking and problem solving (critical thinking and problem solving), communication (communication), and collaboration (Hu et al., 2018; Chai, Koh and Teo, 2019; Kim, Raza and Seidman, 2019). One effort to improve this ability is through the learning process through the heutagogical approach.

The lecturer should be able to encourage the learning process in the classroom focused on the ability of 4Cs namely (1) creativity and innovation, students can find innovative solutions and solve creatively; (2) critical thinking and problem solving, students solve mathematical challenges and are able to make arguments; (3) communication, skilled students communicate verbally and in writing; and (4) collaboration, students can work efficiently in diverse teams (Fitzgerald et al., 2016; Henritius, Löfström and Hannula, 2019; Khlaisang and Songkram, 2019). The right learning process can encourage students to develop these abilities while increasing higher-order thinking skills. Also, lecturers have a role to play in learning activities that can facilitate students to improve higher-order thinking skills (Bacca, Baldiris and Girona, 2018; Haris et al., 2019; Kintu, Kitainge and Ferej, 2019; Lin, 2019).

The development of high-level thinking skills can be improved through the provision of open-ended problems. Also, the acceleration of $4 \mathrm{Cs}$ skills by a lecturer will be able to encourage the use of a complex heutagogical approach (Hu et al., 2018; Tekerek and Karakaya, 2018; Broton, 2019). Through problems that refer to problems in everyday life, students are given the opportunity to contribute, be creative in solving problems using their knowledge and experience. The use of open problems is a matter that is very much considered in learning. The use of open questions in the form of descriptions can provide a space for students to develop strategies and student communication skills (Li, Ren and Wang, 2018; Cohen et al., 2019; Wenting and Lijuan, 2019). Students must be required to have arguments that support problem solving and can communicate the thought process in solving problems. The ability of students to argue, solve problems, construct explanations and be able to hypothesize and understand complex things can improve higher-order thinking skills (Tekerek and Karakaya, 2018; Broton, 2019; Henritius, Löfström and Hannula, 2019). As a result, classroom learning transactions through the heutagogical approach can be systematic with schematic and explorative. 


\section{CONCLUSION}

Aspects of creativity and communication aspects strongly influence the concept of the heutagogical approach. Both of these aspects each contain four elements of need. The need for aspects of creativity includes the ability to develop ideas, the ability to express creative ideas, the ability to adapt to new environments, and the ability to create independently. The need for communication aspects includes the ability to convey information, the ability to deliver ideas, the ability to accept opinions, and the ability to master various communication techniques. Furthermore, approaching heutagogy has characteristics that are influenced by critical thinking and collaboration. In the aspect of critical thinking includes the ability to evaluate, the ability to identify problems, the ability to solve problems well, and the ability to provide facts from assessment. The aspects of collaboration include the ability to cooperate, the ability to be fully responsible, the ability to appreciate opinions, and the ability to interact interactively.

\section{ACKNOWLEDGMENTS}

Thanks to Lembaga Penelitian dan Pengabdian Kepada Masyarakat (LP2M) Universitas Negeri Malang, which has supported this research with the Research and Community Service scheme for the Source of PNBP UM Funds in 2019.

\section{REFERENCES}

Anggariana, I. P. D. et al. (2017). Pengaruh Pembelajaran Problem Based Learning Terhadap Hasil Belajar Matematika Melalui Lesson Study Siswa Kelas III. e-Journal PGSD Universitas Pendidikan Ganesha Mimbar, 5, 1-9.

Bacca, J., Baldiris, S. and Girona, U. D. (2018). Framework for designing motivational augmented reality applications in vocational education and training. Australasian Journal of Educational Technology, 35, 102117.

Bahçıvan, E. (2017). Implementing Microteaching Lesson Study with a Group of Preservice Science Teachers: An Encouraging Attempt of Action Research. International Online Journal of Educational Sciences, 9, 591-602.

Brien, R. O. (2018). Designing For Heutagogy: An Independent Learning Pathway Approach, Capable Scope: Flexible Learning, 2, 59-70.
Broton, K. M. (2019). Rethinking the Cooling Out Hypothesis for the 21st Century: The Impact of Financial Aid on Students 'Educational Goals. Community College Review, 47, 79-104.

Chai, C. S., Koh, J. H. L. and Teo, Y. H. (2019). 'Enhancing and Modeling Teachers' Design Beliefs and Efficacy of Technological Pedagogical Content Knowledge for 21st Century Quality Learning. Journal of Educational Computing Research, 57, 360-384.

Chan, E. Y. M. (2019). Blended Learning Dilemma: Teacher Education in the Confucian Heritage Culture. Australian Journal of Teacher Education, 44, 36-51.

Chidiac, R. S. and Ajaka, L. (2018). Writing Through the $4 \mathrm{Cs}$ in the Content Areas - Integrating Creativity, Critical Thinking, Collaboration and Communication. European Scientific Journal August, 7881, 95-102.

Cirp, P. et al. (2018). Roadmapping towards industrial digitalization based on an Industry 4.0 maturity model for manufacturing enterprises A new methodology to analyze the functional and physical architecture of maturity model for manufacturing enterprises existing products for an assembly oriented product family identification 28th CIRP industrial Roadmapping towards digitalization based. Procedia - CIRP, 79, 409-414.

Cohen, A. et al. (2019). Active learners characterization in MOOC forums and their generated knowledge. British Journal of Educational Technology, 50, 177-198.

Dang, J., Wang, H. and Kang, H. (2019). Analysis on the Current Status and Path of Major Groups Construction in Higher Vocational Colleges. International Workshop on Education Reform and Social Sciences (ERSS 2018), 444448.

Elyakim, N. et al. (2019). Perceptions of Transactional Distance in Blended Learning Using Location-Based Mobile Devices. Journal of Educational Computing Research, 57, 131-169.

Ericson, B. J., Parker, M. C. and Engelman, S. (2016). Sisters Rise Up 4 CS : Helping Female Students Pass the Advanced Placement Computer Science A Exam. SIGCSE, 309-314.

Fitzgerald, H. E. et al. (2016). The Centrality of Engagement in Higher Education: Reflections and Future Directions. Journal of Higher Education Outreach and Engagement, 20, 245-254.

Fırat, M., Kılınç, H. and Yüzer, T. V. (2018). Level of intrinsic motivation of distance education students in elearning environments. Journal of Computer Assisted Learning, 34, 63-70.

Forster, A. G. and Bol, T. (2018). Vocational education and employment over the life course using a new measure of occupational specificity. Social Science Research, 70, 
176-197.

Green, R. D. and Schlairet, M. C. (2017). Moving toward heutagogical learning: Illuminating undergraduate nursing students, experiences in a fl ipped classroom. Elsevier - Nurse Education Today, 49, 122-128.

Handajani, S., Pratiwi, H. and Mardiyana. (2018). The 21st century skills with model eliciting activities on linear program, Journal of Physics: Conf. Series, 1-7.

Haris, A. et al. (2019). Effectiveness of Entrepreneurship Communication Skills in Business Group: Ethno-Andragogy Approach to Technical Vocational Education and Training, in 5th UPI International Conference on Technical and Vocational Education and Training (ICTVET 2018) Effectiveness, 179-182.

Hashim, S. et al. (2019). Knowledge Construction Process in Open Learning System among Technical and Vocational Education and Training (TVET) Practitioners. Journal Of Technical Education And Training, 11, 73-80.

Henritius, E., Löfström, E. and Hannula, M. S. (2019). Emotions in virtual learning: A review of empirical research in the 21st century. British Journal of Educational Technology, 50, 80-100.

$\mathrm{Hu}$, J. et al. (2018). Strategic planning and the stratification of Chinese higher education institutions International Journal of Educational Development Strategic planning and the strati fi cation of Chinese higher education institutions. International Journal of Educational Development, 1-8.

Idris, R. (2019). Industrial Revolution 4.0: An Overview of Readiness and Potential Economic Effects in Malaysia from Millennials Perspective. World Scientific News, 118, 273-280.

Irdianto, W. and Putra, A. B. N. R. (2016). The Influence of Education and Economic Background Towards The Training Participants Motivation and Study Result of UPT-PK Singosari Malang. AIP Conference Proceeding, 1-7.

Ivanov, L. (2016). The 4Cs of cultural diversity in consumer research: a literature review and research agenda. The Bulletin of the Dnipropetrovsk university, 24, 194-200.

Jantan, A. H. et al. (2018). Fourth Industrial Revolution In Developing Countries: A Case On. Journal of Management Information and Decision Sciences, 21, 1-9.

Jones, C. (2016). Enterprise Education: Towards the Development of the Heutagogical Learner. AISHE-J, 8, 2541-25417.

Jose, R. and Ramakrishna, S. (2018). Materials 4.0: Materials big data enabled materials discovery. Elsevier Applied Materials Today. Ltd, 10, 127-132.

Jossberger, H. et al. (2018). Learning in Workplace Simulations in Vocational Education: a Student
Perspective. Vocations and Learning, 11, 179-204.

Karlsson, T., Nilsson, F. L. and Nilsson, A. (2018). Vocational Education and Industrial Relations: Sweden 1910-1975. Nordic Journal of Educational History, 5, 27 50.

Khlaisang, J. and Songkram, N. (2019). Designing a Virtual Learning Environment System for Teaching Twenty-First Century Skills to Higher Education Students in ASEAN. Springer - Technology, Knowledge and Learning, 24, 41-63.

Kim, S., Raza, M. and Seidman, E. (2019). Improving 21 st-century teaching skills: The key to effective 21 stcentury learners. Research in Comparative \& International Education, 14, 99-117.

Kintu, D., Kitainge, K. M. and Ferej, A. (2019). An Exploration of Strategies for Facilitating Graduates , Transition to the World of Work: A Case of Technical, Vocational Education and Training Graduates in Uganda. International Journal of Vocational Education and Training Research, 5, 1-9.

Lang, C. et al. (2017). Teaching Stress Management in Physical Education: A Quasi-Experimental Study with Vocational Students. Scandinavian Journal of Educational Research,1-13.

Li, Z., Ren, Y. and Wang, W. (2018). Teaching Reform of Computer Basis Course based on MOOC. Advances in Social Science, Education and Humanities Research, 381385 .

Lin, M. (2019). Challenges and Opportunities for Technical and Vocational Education and Training in the local communities: Education and Labour Market for Young People. International Journal of Social Science Studies, 7, 1-15.

Mahmood, M. F. and Hussin, N. (2018). Information in Conversion Era: Impact and Influence from 4th Industrial Revolution. International Journal of Academic Research in Business and Social Sciences, 8, 320-328.

Malek, J. A. (2017). The Impact Of Heutagogy Education Through Telecentre In Smart Village (SV). Journal of Social Sciences and Humanities, 12, 112-125.

Marcut, I. G. and Chisiu, C. M. (2018). Heutagogy An Appropriate Framework For Computer Aided Learning Course With Post-Graduate Teacher Students. Journal Plus Education, 21, 203-215.

MayTruong, H. (2016). Integrating learning styles and adaptive e-learning system: Current developments, problems and opportunities. Elsevier-Computers in Human Behavior, 55, 1185-1193.

McCarthy, Stoszkowski, L. and and Robert, J. (2018). A heutagogical approach to coach education : what worked for one particular learner, how and why. Journal of Qualitative Research in Sports Studies, 12, 317-336. 
Mcguinness, C. and Fulton, C. (2019). Digital Literacy In Higher Education: A Case Study Of Student Engagement With E-Tutorials Using Blended Learning. Journal of Information Technology Education: Innovations in Practice, 18, 1-28.

Melo, M. (2018). The 4C/ID-Model in Physics Education: Instructional Design of a Digital Learning Environment to Teach Electrical Circuits. International Journal of Instruction, 11, 103-122.

Mesfin, M. D. and Niekerk, E. J. Van. (2019). Leadership Styles Of The Deans In Ethiopian Governmental Technical And Vocational Education And Training (Tvet) CollegeS. European Journal of Social Sciences Studies, 4, 123-141.

Montgomery, A. P. et al. (2019). Using learning analytics to explore self-regulated learning in flipped blended learning music teacher education. British Journal of Educational Technology, 50, 114-127.

Mudin, D. K. D. et al. (2018). Industrial revolution 4.0: Universiti Malaysia Sabah perspective. E3S Web of Conferences, 48, 1-4.

Mukhadis, A. et al. (2018). The Relevance of Vocational High School Program With Regional Potency Priority in Indonesia. Journal of Physics: Conference Series, 1028, 1-8.

Mukri, M. and Anwar, S. (2019). Quran-integrated science in the era of industrial revolution 4.0. Paper presented at IOP Conf. Series-Journal of Physics, 1-5.

Mulrennan, D. (2018). Mobile Social Media and the News: Where Heutagogy Enables Journalism Education. Journalism \& Mass Communication Educator, 73, 322 333.

Murtikusuma, R. P. et al. (2019). The development of interactive mathematics learning media based on schoology and visual basic through industrial revolution 4.0. Paper presented at IOP Conf. Series: Earth and Environmental Science, 1-6.

Narayan, V., Cochrane, T. and Herrington, J. (2019). Design principles for heutagogical learning: Implementing student- determined learning with mobile and social media tools. Australasian Journal of Educational Technology, 35, 86-101.

Newton, D. et al. (2018). The Impact of Vocational Education and Training Programs on Recidivism: A Systematic Review of Current Experimental Evidence. International Journal of Offender Therapy and Comparative Criminolog, 62, 187-207.

Oliver, E. (2016). A move towards heutagogy to empower theology students. Theological Studies, 72, 1-7.

Owston, R., York, D. and Malhotra, T. (2018). Blended learning in large enrolment courses: Student perceptions across four different instructional models Blended learning in large enrolment courses: Student perceptions across four different instructional models. Australasian Journal of Educational Technology, 35, 29-45.

Placklé, I. et al. (2018). Students embracing change towards more powerful learning environments in vocational education. Educational Studies, 44, 26-44.

Praherdhiono, H., Adi, E. P. and Prihatmoko, Y. (2018). Strengthening Performance for Teachers in Early Childhood Education with Heutagogy on t26-44he Utilization of Digital Learning Media and Sources. Advances in Social Science, Education and Humanities Research (ASSEHR), 244, 74-79.

Putra, A. B. N. R. et al. (2018). Inovasi pembelajaran mutakhir dengan mind mapping dalam upaya meningkatkan kompetensi expert dan akselerasi pola pikir mahasiswa. Jurnal Teknik Otomotif Kajian Keilmuan dan Pengajaran, 1, 8-15.

Putra, A. B. N. R., Irdianto, W. and Mukhadis, A. (2016). Pocket Book Learning: Learning Methods to Train Students Productive and Creative using BRANO as an Effective Learning Recorder. Paper presented at AIP Conference Proceeding, 1-7.

Putra, A. B. R. N. et al. (2018). Occupational Health And Safety (OHS) management for employees on the risk of diseases due to the intensity of computer use in the workplace/industry. MATEC Web of Conferences, 1-6.

Rahman, R. et al. (2019). Elementary Education Literacy in the Era of Industrial Revolution 4.0. in UPI 2nd International Conference on Language, Literature, Culture and Education (ICOLLITE 2018) Elementary, 190-193.

Ramírez, P. A. M. (2019). E-Learning in the development of school scientific thinking in the Physics classroom. REVISTA CIENTÍFICA, 121-130.

Richardson, L. P., Mcgowan, C. and Styger, L. (2017). Heutagogy - An updated approach to Masters Education Paper presented at 20th International Conference, 703-718.

Robi, A. A., Hobri and Dafik (2018). The Analysis of Critical Thinking Skill of Version P21 in Solving the Problems of Two Dimensional Arithmetic Derived from the Implementation of Guided Discovery Learning. International Journal of Scientific Research and Management, 06, 6-13.

Santos, L. et al. (2018). International Journal of Production Economics The expected contribution of Industry 4 . 0 technologies for industrial performance. International Journal of Production Economics, 204, $383-$ 394.

Simarmata, J., et al. (2018). Design of a Blended Learning Environment Based on Merrill's Principles Design of a Blended Learning Environment Based on Merrill's Principles. Paper prensented at IOP Conf. Series: Journal of Physics, 1-5. 
Skorton, D. (2019). Branches from the same tree: The case for integration in higher education. Direct Submission, 116, 1865-1869.

Ślusarczyk, B. (2018). Industry 4.0-Are We Ready?. Polish Journal Of Management Studies, 17, 323-248.

Smirnova, Z. V et al. (2019). Practice-oriented approach implementation in vocational education. Paper prensented at IOP Conf. Series: Materials Science and Engineering, 1-5.

Stoszkowski et al. (2018). Students ' perceptions of the learner attributes required for (and resulting from) heutagogical learning. Journal of Learning Development in Higher Education, 14, 1-12.

Stoszkowski, J. and Collins, D. (2018). Article The Agony and the Ecstasy: Student-Coaches Perceptions of a Heutagogical Approach to Coach Development. International Sport Coaching Journal, 5, 1-30.

Tekerek, B. and Karakaya, F. (2018). STEM Education Awareness Of Pre-Service Science Teachers. International Online Journal of Education and Teaching, 5, 348-359.

Thakur, G. (2017). Heutagogical Learning Efficiency Model To ICT Integration in the Classroom. International Scientific Journal of Contemporary Research in Engineering, Science and Management (ISJCRESM), 2, 15.

Thunqvist, D. P., Tønder, A. H. and Reegård, K. (2019). A tale of two reforms: Institutional change in vocational education and training in Norway and Sweden in the 1990s. European Educational Research Journal, 1, 115.

Vu, T. L. A. and Le, T. Q. (2019). Development orientation for higher education training programme of mechanical engineering in industrial revolution 4 . 0: A perspective in Vietnam Journal of Mechanical Engineering Research \& Development Orientation For Higher Education Training Programm. Journal of Mechanical Engineering Research and Developments, 42, 68-70.

Wenting, M. and Lijuan, Y. (2019). Exploration of Blended Teaching Mode Reform Based on MOOC-Taking Advanced Mathematics as an Example. Paper presented at 6th International Education, Economics, Social Science, Arts, Sports and Management Engineering Conference (IEESASM 2018) Exploration, 32-35.

Woessmann, L. (2019). Facing the life-cycle trade-off between vocational and general education in apprenticeship systems: An economics-of-education perspective. Journal for Educational Research Online, 11, 31-46.

Yakar, Z. and Turgut, D. (2017). Effectiveness of Lesson Study Approach on Preservice Science Teachers' Beliefs. International Education Studies, 10, 36-43.

Zabidin, N. S., Belayutham, S. and Ibrahim, C. K. I. C. (2019). A Bibliometric Analysis of Industrial Revolution
(IR) 4.0 in Construction Engineering Education. Paper presented at MATEC Web of Conferences, 1-6.

Zaharah, S. et al. (2018). Industry 4.0: A Systematic Review in Technical and Vocational Education and Training. Jurnal Psikologi Malaysia, 32, 66-74.

Zambon, I. et al. (2019). Revolution 4.0: Industry vs. Agriculture in a Future Development for SMEs. Processes, $36,1-16$.

Zulkarnaen, R. H. et al. (2019). Smart city design in learning science to grow 21 st century skills of elementary school student. Paper presented at IOP Conf. Series: Journal of Physic, 1-7. 